\title{
Artisanal Fishing in Beira, Central Mozambique
}

\author{
Dan Darkey and Ruth Turatsinze \\ Department of Geography, Geoinformatics and Meteorology, University of Pretoria, \\ Pretoria, South Africa
}

\begin{abstract}
KEYWORDS Fishing Gear. Over-exploitation. Marine Ecosystem. Mozambique
ABSTRACT The study focuses on artisanal fishing in Beira, located within the most important fishery area of Mozambique - the Sofala Bank in central Mozambique. The main aim is to establish the degree of compliance with artisanal fishing regulations by artisanal fishermen in light of an increasing concern for the impact of fishing on ecosystems and livelihoods. Qualitative research data was gathered through semi-structured interviews with fishermen, officials from the Department of Fisheries and major stakeholders from the Institute for the Development of Small Scale Fisheries (IDSSF), the National Institute for Fishery Research (NIFR) and the Community Fishing Centres (CFCs). Though a review of the regulations and policies for the management of artisanal fishing in Mozambique indicate that they are well formulated and relevant, there is little to no compliance by the practitioners of artisanal fishing. The data revealed that artisanal fishermen in Beira use types of fishing gear which catches immature and juvenile fish and poses a threat to the health of the marine ecosystems. The most dangerous of these fishing gears are the mosquito net traps (known as "chicocota") and the beach seine. It is clear that the application and enforcement of the relevant regulations under the right circumstances would lead to better management of the fisheries environment and ensure the sustainability of artisanal fishing.
\end{abstract}

\section{INTRODUCTION}

Fisheries provide basic food supplies, employment, livelihoods, a source of foreign currency and recreational opportunities for many people living in coastal rural communities and urban societies (Cochrane and Garcia 2009; Ghosh 2012). According to the United Nation's Food and Agriculture Organization (FAO), this is the case in Mozambique, a country with a vast coastal environment of approximately 3000 $\mathrm{km}^{2}$ which contains diverse and valuable ecosystems of high productivity and biodiversity, and which offers unique habitats to many species (FAO 2009). Indeed Mozambique's offshore open waters support productive marine ecosystems and provide a source of livelihood for many. The Mozambican seawaters support about 1500 fish species of which 400 have direct commercial value (Hara et al. 2001). The most important marine species include prawns, deepwater shrimp, lobster, demersal and pelagic species, tuna species and octopus (FAO 2007).

Address for correspondence:

Dr. Dan Darkey

Department of Geography,

Geoinformatics and Meteorology,

University of Pretoria,

Pretoria, 0002, South Africa.

Phone: +27 124203710 .

Mobile: +27 828526782. Fax: +27 4206385

E-mail: daniel.darkey@up.ac.za
Artisanal fishing is an important activity of Mozambique's coastal zone. It provides a source of employment and livelihood to several impoverished communities, particularly in Beira. However, over the last decade, fishing activities have become a serious threat to Mozambique's marine environment (Blythe et al. 2014). There is also increasing concern about the management of fisheries resources and fishing methods, which are threatening the size and structure of the target fish species and subsequently endangering this way of life in several areas of the vast Mozambican coastal zone (FAO 2007). For instance, the FAO assessment of the prawn stocks in Mozambique shows that they have been over-exploited to the extent that fish size and quality has diminished. It is acknowledged that some of the major challenges facing fishing and fishing environments, the world over relate to habitat destruction, climate variability and the way in which the resources are being extracted (Goldie et al. 2005; Lee and Midani 2013; Paul et al. 2014).

In light of this, the study focuses on the fishing gear used by artisanal fishermen in Beira, which is located within one of the most important fishery areas of the country, the Sofala Bank (central Mozambique). The main aim is to critically evaluate compliance with artisanal fishing regulations in the study area. Thus, the research seeks not only to establish the risks associated with artisanal fishing gear and the extent to which fishermen depend on such gear but also estab- 
lish artisanal fishermen's awareness of and the degree to which they comply with existing fishing policies and regulations. Furthermore fishermen's levels of awareness of environmental impacts caused by certain artisanal fishing gears are established and the effectiveness of management of the marine ecosystems and fishery resources through official monitoring of compliance to regulations is evaluated.

The study report is presented in six parts. The introduction is followed by literature review which provides an overview of fishing in Mozambique. Third is an outline of the study area which is followed by a description of data collection procedures and data analysis. The fifth section investigates how artisanal fishing activities comply with the regulations governing the industry. The final section draws conclusions and makes recommendations.

\section{Overview of Fishing in Mozambique}

The main fishing areas in Mozambique are located along the marine coast from Maputo Bay to the Northern Province of Cabo Delgado, with the major concentration found at the Sofala Bank in central Mozambique. Typical of richly endowed fishing environments, there are different types of fishing activities in coastal Mozambique including subsistence, commercial, industrial, experimental, recreational and artisanal (Government Gazette No. 39 1990).

Artisanal fishing in Mozambique, the focus of this study, is often regarded as the small-scale fishing sector which includes both artisanal subsistence fishing and commercial fishing (IDSSF 2009). According to the artisanal fishing census carried out in 2007 there are 595 artisanal fishing centres along the Mozambican coastal provinces with the northern and central regions having the highest number (IDSSF 2003). The fishing gear commonly used in artisanal fisheries consists of beach seines, gillnets, traps, hand-lines, long lines, and others (Department of Fisheries and IDSSF 2009). However, it is believed that artisanal fishermen in several coastal areas of Mozambique including Beira also use mosquito nets or nets with a fine mesh size like mosquito nets as part of their fishing gear.

\section{Legal Framework for Marine and Fisheries Management}

Mozambique, like many developing countries, has the goal of achieving sustainable de- velopment (Glazewski 2005). Since the marine ecosystem and fisheries contribute immensely to the daily sustenance of the people of Beira, there is a need to link the fishing activity with initiatives that sustain these services. Aware that effective and successful management of the fisheries is only possible within a suitable and functional legal framework, the government of Mozambique has embraced policies and legislation designed to guarantee the ecological balance, conservation and preservation of the environment and its natural resources including fishery ecosystems (Ministry of Fishing and IDSSF 2009). Realizing that a legal framework is a fundamental instrument in managing not only the commercial but also the subsistence fishing sector the government, in addition to the Constitution of the Republic of Mozambique (1990), put in place the Fishing Act of 1990 (Government Gazette No. 39 1990) and the General Regulation for Marin Fishing Act 43 of 2003 (Government Gazette No. 5 2003) among other key legislation that attempts to regulate fishing in Mozambique.

Fishing is an activity which many people living in the coastal regions of the Mozambican coast engage in. Because the nutritional needs of many people in Mozambique are met in part by fish and shellfish consumption, the Constitution's Bill of Rights includes clauses and provisions intended to protect these. Chapter three, section 117, which is related to the environment and quality of life states, for instance, that:

- The State shall promote efforts to guarantee the ecological balance and the conservation and preservation of the environment, with a view to improving the quality of life of its citizens.

- With a view to guaranteeing the right to the environment within the framework of sustainable development, the State shall adopt policies aimed at:

a. Integrating environmental objectives with sectoral policies;

b. Promoting the integration of environmental values into educational policies and programmes;

c. Guaranteeing the rational utilization of natural resources and the safeguarding of their capacity to regenerate ecological stability and the rights of future generations. 
Chapter Two of the Constitution further emphasizes that the government of Mozambique "shall promote knowledge of, surveys on and the valorization of natural resources, and shall determine the conditions under which they may be used and developed subject to national interests" (Constitution of the Republic of Mozambique 1990). The marine ecosystems and the services they provide to the Mozambican people constitute a source of natural resources whose sustainable utilization is paramount.

The Fishing Act and the General Regulations for Marine Fishing are the main legislation that determines the terms according to which and the conditions under which fishing activity must be undertaken (Government Gazette No. 39 1990). These instruments set out guidelines for fisheries monitoring, control and surveillance, license conditions and technical specifications for fishing gears, methods and vessels, and also provide for the implementation of measures to protect fisheries resources. For instance, these regulations provide for the management of marine ecosystems through the establishment of an immediate inshore zone, up to one mile (1.6 kilometres) from the high water line, which is exclusively reserved for artisanal fishing. In certain locations, including Beira, this area is extended to three miles (Government Gazette No. 39 1990). The size of the mesh used in fishing gears is provided for in section 33 of the General Regulation of the Marine Fishing Act 43 of 2003 and section 22 of the Fisheries Act of 1990, which for example set a minimum size of $38 \mathrm{~mm}$ for all beach seines. The regulations further provide for the implementation of other measures to protect marine resources (Constitution of the Republic of Mozambique 1990, Government Gazette No. 39, 1990, Government Gazette no. No. 5, 2003)

The Ministry for the Co-ordination of Environmental Affairs recognizes that the protection of the environment and rational management of the natural resource base are absolute requirements for any successful development programme, and seeks to make environmental conservation a fundamental, crosscutting theme in its proposed programme. The main objectives of the 1995 National Environmental Policy are to: ensure that the environment and natural resources are managed in such a way that they maintain their functional and productive capacity for the present and future generations; promote local community participation in the plan- ning and decision-making process on the use of natural resources; protect ecosystems and the fundamental ecological processes; and link with global and regional efforts in the search for solutions to environmental problems (NEMP 1995).

\section{Artisanal Fishing Management in Mozambique}

As the pressures on marine ecosystems and fishery resources are increasing in Mozambique, there is a critical need to manage both the environment and resources to help minimize overexploitation and other negative impacts on marine ecosystems. The various entities working to improve the management of marine resources in Mozambique include the Department of Fisheries, the IDSSF, the CFCs and the NIFR.

The IDSSF was designed to promote and assist the development of the small-scale fishing sector with the ultimate objective to reduce poverty and improve the lifestyle of artisanal fishermen. It is involved in several projects, including strategic planning for the artisanal fishing sector and oversees the fishery development fund (IDSSF 2006). The NIFR, on its part, is the institution responsible for conducting scientific research on the marine resources along the Mozambique canal in order to have updated information on the state of fisheries in the canal. The NIFR also produces quarterly and/or annual reports that, among others, contain data on the annual catch effort of artisanal fishing in each province of Mozambique. For the 2010 period, for instance, the catch from artisanal fishing in Sofala Province, which includes Beira, was estimated at 18811.5 tones. For the same period the output from artisanal fishing in Mozambique was about 82607 tones, while in 2009 the catch was 83473 tones (NIFR 2010). The CFC was introduced by the Department of Fisheries and the IDSSF in 2005 as a strategy to improve artisanal fishing management. The CFC operates in a system of co-management with the Department of Fisheries, with the following competencies: licensing mediation; conflict mediation among fishermen; control and monitoring of fishing activity; and tax collection. The department's duties include producing a monthly report for the provincial department of fisheries on all the artisanal fishing activities undertaken in the given period. 
The Department of Fisheries has put in place measures to monitor and manage fisheries in Mozambique and these include the census on artisanal fishing carried out by the ministry and the IDSSF. The census assesses socio-economic, technological and partial ecological information on artisanal fishing in the country. The data gathered in the census include the number of fishing centres, the number of fishermen, the number of boats and the type of fishing gears used (IDSSF 2009).

Given that fishery resources constitute a primary source of employment and livelihood for many people in Mozambique, fisheries management is of great importance as it ensures that fishing does not result in excessive or irreversible damage to the fish stocks and the integrity or structure of the ecosystems (Cochrane and Garcia 2009). In addition, the proper use and management of this environment and its resources will ensure benefits for both the present and future generations of Mozambicans as highlighted in the National Environmental Management Programme (NEMP 1995). Sound as the fishing regulatory frameworks and monitoring institutions may be, the core challenge facing artisanal fishing in coastal Mozambique, like in neighbouring South Africa, is compliance (Brill and Raemaekers 2013)

\section{The Study Area}

The four sites (from Beira) selected for the study are: Praia Nova, Palmeiras, Biques (Macúti) and Njalane (see Fig. 1 for the location of these sites). The common features of all four sites are a high concentration of fishing activity and dire socio-economic conditions under which local people live. In the following section a brief background to these locations is provided.

Beira, Mozambique's second largest city is located in central Mozambique and is the capital city of Sofala Province. The coastal zone of Beira is considered an estuarine environment which is produced by several rivers discharging into a bay (Hoguane 1998). The area is characterized by excellent conditions for fisheries because of the unique ecosystem based on a river, ocean and front interaction, as well as habitats such as mangrove forests that provide the right conditions and nutrition for many fish species (The EAME 2007). Beira is located within the Sofala

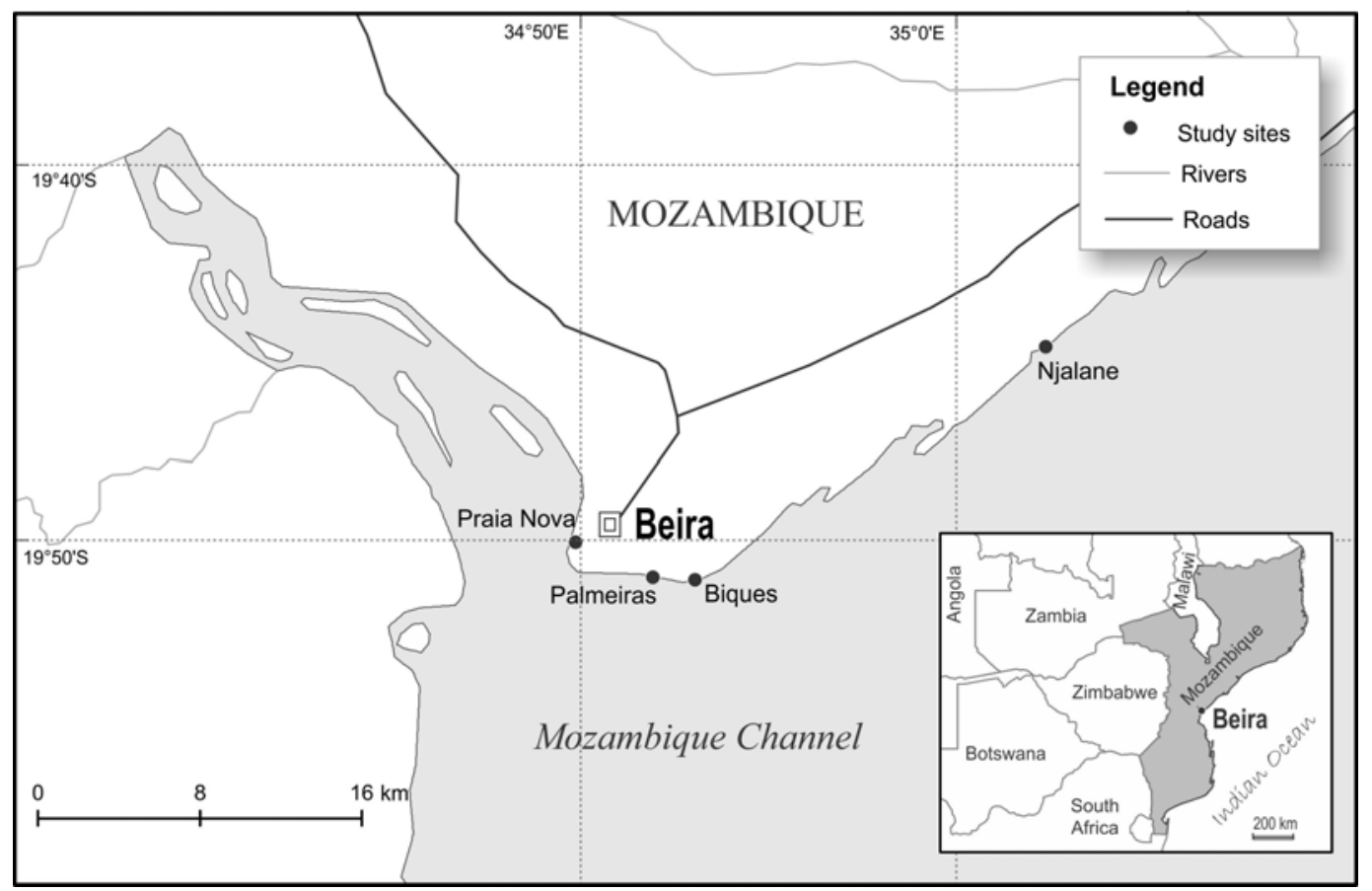

Fig. 1. Map of the study area (Adapted from Google earth 2012) 
Bank, the major and most important fishing area in Mozambique and, therefore, constitutes a good site for the study.

Praia Nova is located in downtown Beira. The Praia Nova site is part of an estuarine environment in which the Búzi River flows into the sea. Fishing is exercised along the marine environment of Beira and within the three miles into the sea approved by law. Many of those who exercise commercial fishing activity in Praia Nova use motorboats. However, subsistence fishermen use canoes. The total number of artisanal fishermen involved in fishing activity in this site in 2011 was estimated at about 200 by the researcher.

Palmeiras has been home for artisanal fishing activity for decades though the area is not recommended for fishing - not only owing to its shallow water, but also because it is one area where untreated sewage water flows into the sea (NIFR 2010). Palmeiras is a poor 'downtown' community and artisanal fishermen in this site are impoverished people who undertake the activity in order to sustain their families. The most common gear used by artisanal fishermen at the Palmeiras site is the mosquito net trap named chicocota by local fishermen. The total number of artisanal fishermen involved in fishing activity in this site in 2011 was about 60.

Biques like Palmeiras is characterized by low income households that practice fishing as a source of livelihood. The main fishing gear used is the chicocota trap and the type of boat used by the fishermen is the canoe. The total number of artisanal fishermen involved in fishing activity in this site in 2011 was about 50.

In Njalane, $98 \%$ of the houses are built with local material and the people living there are very disadvantaged and live in very poor conditions. Access to the fishing area is through a mangrove forest and a river which provide home and nutrition to several fish species. Njalane has a miscellaneous group of fishermen comprising both local fishermen (from Beira) and some fishermen from Moma district in Nampula (the latter come to fish in Njalane because fishing resources have started becoming scarce in their zone of origin). The main fishing gear in this site includes gillnets, beach seines and hand-lines.

\section{STUDY METHOD}

Data collection was done in May-June 2011 when the provincial Department of Fisheries in
Beira was approached and full collaboration and permission was obtained for conducting the study. A variety of data collection techniques including interviews and field observations were used. Critical desk top analysis of the regulations and policies for artisanal fishing has also substantially contributed to the outcome of this study.

\section{Interviews}

Two sets of questionnaires were devised for the interviews. One was strictly designed to interview the artisanal fishermen and the other to interview all the other stakeholders in the fishing sector, including officials from the Department of Fisheries, IDSSF, NIRF and representatives of the fishing centres.

Semi-structured interviews were conducted with selected artisanal fishermen and stakeholders. Once the researcher accessed the total number of fishermen in each site, a selection of $10 \%$ of the fishermen to be interviewed was made without any prearranged or specific order. The selection of the fishermen was not based either on age or years of fishing practice but rather on the fact that they were exercising the activity at the time of the research data collection. Different times and days were used for the interviews.

Support from the Department of Fisheries was overwhelming. The provincial director showed great interest in the outcome of this study and provided important information on artisanal fishing activity in Beira. The whole task force of the Department of Fisheries responsible for controlling and monitoring artisanal fishing activity was encouraged by the provincial director to actively participate, providing the researcher required information.

\section{Observation}

The observation of artisanal fishing activity at various sites (Praia Nova, Palmeiras, Biques and Njalane), in Beira city was non-participant. With non-participant observation, the researcher spent a few days observing the fishermen, the environment and the dynamics of the fishing activity from a distance. The observations took place without any interaction between the researcher and the fishermen. Also observed are lifestyles, family activities and interactions. The main aim of this method was to assess the prac- 
tices, methods and levels of compliance and to record these observations before beginning the interviews.

These interviews, of both fishermen and key stakeholders - which included key government officials from the Departments of Fisheries, the IDSSF and the NIRF provided the information necessary for analyzing the trends of compliance with artisanal fishing in the study area. Secondly, the on-site observation of fishing activities provided complementary information on fishing techniques/methods and levels of compliance to regulations. Furthermore, the analysis of the policies and practices contributed to assessing the extent to which current legislation is assisting the management of artisanal fishing.

\section{FINDINGS AND DISCUSSION}

The study findings are discussed in the following section focusing on the characteristics of artisanal fishing, the risks posed to the ecosystem by the activity, the levels of awareness of fishing regulations by participants, the monitoring systems for compliance to regulations and the degree of compliance to these regulations by the fishermen.

\section{Demographic Profile of Fishermen and Characteristics of Artisanal Fishing in Beira}

Fishing in Beira is mainly done by males. The demographic profile of the fishermen shows that the average size of their household is approximately six people (Table 1). Although some fishermen declared themselves single, most of them do have a partner, some more than one, and children. The average age of the fishermen from the four study sites is 34 years with the fishermen from Praia Nova slightly older at 40 years. Most of the fishermen started their fishing activities at an early age while others joined the activity between the ages of 15 and 20 with the ultimate goal of providing a livelihood for their families.

Apart from a mere $6 \%$ of commercial fishing in Praia Nova, all the fishermen are engaged in artisanal fishing, which is a primary source of income. The artisanal fishing boats in Beira are wooden canoes of 5 to 10 metres and sailing crafts known as "lanchas" of which fewer than $5 \%$ are motorized. At Palmeiras and Biques, canoes are the only vessels used. On the other hand, in Praia Nova and Njalane two types of boats were found - canoes and lanchas, the latter accounting for more than $60 \%$, with most of them equipped with an engine. By and large, the vessels used in Beira are old and inappropriate for efficient fishing. They are also not equipped with navigation devices, fish detection systems or any kind of safety accessory such as life jackets. The fishermen depend on their own swimming skills in case of any mishap.

Usually, the types of species caught by artisanal fishermen in Beira using the conventional gillnet, beach seine and hand-line include shrimps and various types of fish (see Table 2). Daily catch output varies considerable with 200 kilograms as the upper limit. However, if the weather is not good, the average catch per day could be as low as 7.5 kilograms.

Assessment done during the field visit revealed that the most productive months for fishing are between May-July and November-December. May marks the end of the closed season for commercial and industrial fishing when the marine environment is set aside for species to mature. Another characteristic of fishing in Beira is the types of fishing gear used for artisanal fishing. These include gill net and hand-line, beach seining and the chicocota or mosquito net - which is the most popular gear in all the fishing locations except Njale. A chicocota fishing trap is made from old otter-trawl net pieces

Table 1: Demographic profile of fishermen in the study area

\begin{tabular}{|c|c|c|c|c|c|c|}
\hline \multirow[t]{2}{*}{ Site } & \multicolumn{2}{|c|}{ Type of artisanal fishing } & \multicolumn{2}{|c|}{ Marital status } & \multirow{2}{*}{$\begin{array}{l}\text { Average } \\
\text { household } \\
\quad \text { size }\end{array}$} & \multirow{2}{*}{$\begin{array}{c}\text { Average } \\
\text { age }\end{array}$} \\
\hline & $\begin{array}{l}\text { Subsistence } \\
\text { (\%) }\end{array}$ & $\begin{array}{c}\text { Commercial } \\
(\%)\end{array}$ & $\begin{array}{c}\text { Married } \\
(\%)\end{array}$ & $\begin{array}{c}\text { Single } \\
(\%)\end{array}$ & & \\
\hline Praia Nova & 94 & 6 & 65 & 35 & 7 & 40 \\
\hline Palmeiras & 100 & 0 & 75 & 25 & 6 & 33 \\
\hline Biques & 100 & 0 & 84 & 16 & 5 & 30 \\
\hline Njalane & 100 & 0 & 64 & 36 & 5 & 34 \\
\hline
\end{tabular}


Table 2: Species caught by artisanal fishermen in Beira

\begin{tabular}{llll}
\hline Praia Nova & Palmeiras & Biques & Njalane \\
\hline Bearded croaker & Bearded croaker & Bearded croaker & Bearded croaker \\
Blacktip sea catfish & Black pomfret & Blacktip sea catfish & Black pomfret \\
Bloodspotted crad & Flathead mullet & Indian anchovy & Fourline tonguesole \\
Bull shark & Indian anchovy & Knight rock shrimp & Goldstripe sardinella \\
Flathead mullet & Knight rock shrimp & Largehed hairtail & Indian pellona \\
Gold stripe sardinella & Orangemouth thryssa & Medusa & Kelee shad \\
Greasy grouper & Silver sillago & Orangemouth thryssa & Narrow barred \\
Javelin grunter & Tsivakihini paste shrimp & Tsivakihini paste shrimp & Spanish mackerel \\
Kelee shad & & & Orangemouth thryssa \\
Knight rock shrimp & & & Tigertooth croaker \\
Orangemouth thryssa & & & Tsivakihini paste shrimp \\
Tigertooth croaker & & & \\
Torpedo scad & & & \\
\hline
\end{tabular}

and takes a cone-shaped form with a cod-end normally featuring a fine mesh size (NIFR 2008).

In Palmeiras and Biques, for instance the level of dependency on the chicocota for artisanal fishing is extremely high, accounting for $100 \%$ of gear employed, whereas beach seine is not used at all. Njalane is the only site that does not use the chicocota, with the beach seine serving as the principal fishing gear - accounting for $62 \%$ usage (see Table 3 ).

Table 3: The most popular artisanal fishing gear in Beira

\begin{tabular}{lcccc}
\hline & \multicolumn{4}{c}{ Level of dependency (\%) } \\
\cline { 2 - 5 } & Chicocota & Gillnet & $\begin{array}{c}\text { Hand- } \\
\text { line }\end{array}$ & $\begin{array}{c}\text { Beach } \\
\text { seine }\end{array}$ \\
\hline Praia Nova & 22 & 66 & 6 & 6 \\
Palmeiras & 100 & - & - & - \\
Biques & 100 & - & - & - \\
Njalane & - & 8 & - & 62 \\
\hline
\end{tabular}

Officials from the Department of Fisheries attribute the causes of the high percentage of dependency on destructive fishing gear to: lack of knowledge of the policies and regulations guiding the fishing sector; non-compliance with the regulations and policies; poor management of this sector which makes it difficult to enforce the laws; the mosquito net traps is less expensive and; the high percentage of illiteracy among the artisanal fishermen. According to officials from the Department of Fisheries the high illiteracy rates of fishermen, estimated at $90 \%$ explains why so many of them still use gear such as the chicocota. On the other hand, the fishermen claim that certain species can only be caught by using such gears. What is certain is that the risks posed by the use of such gears are enormous. Indeed the use of mosquito nets (which have an extremely fine mesh) results in larvae and juvenile fish being caught before they mature and spawn.

\section{Monitoring and Control of Artisanal Fishing in Beira}

According to Government Gazette no. 39 of 26 September 1990, article 52(1) “... the practice or attempt to exercise the artisanal fishing, semiindustrial or industrial activity in Mozambican's jurisdiction waters by fishermen or fishing vessels without all the required documents such as license acquired under local Regulations and Policies shall be punished with a fine and confiscation of all the goods including the catch and the boat/vessel" (Government Gazette 1990). The monitoring and control of artisanal fishing activity aims to enforce fishing regulations and improve the management of fishing activity. Artisanal fishermen are required to hold a license in terms of articles 50, 51 and 52 of the Fishing Act of 1990. Mosquito nets and fine mesh nets, which are illegal, are often confiscated during the monitoring and control operations and are eventually destroyed.

The Department of Fisheries is the main entity responsible for the monitoring and control of artisanal fishing activity in Beira; however, the Department of Fisheries has delegated part of its responsibility to the Community Fishing Centre (CFC). The CFC is obliged to write a monthly report to the provincial Department of Fishing addressing matters such as tax collection through licensing and artisanal fishing gears. However, the ground research assessed that 
Praia Nova is the only fishing centre that produces the report once a year.

The provincial Department of Fisheries has a task force of six members to oversee the artisanal fishing sector in Sofala Province which includes Beira. Half of the task force group members were appointed in 2007 while the other three were deployed before 1996 . The most experienced task force member has more than 20 years in the field. In terms of education, the task force members have $12^{\text {th }}$ grade (completed high school education) or have attended a professional fishing school where basic knowledge of the fishing sector, regulations and its dynamics was acquired. Apart from the standard education, the provincial Department of Fisheries has offered occasional training. Training has a maximum duration of 90 days and usually has been offered in neighbouring countries such as South Africa, Madagascar and Namibia (Vas 2011).

The task force group has complained about the logistic problems encountered in the monitoring of artisanal fishing in Beira (Sofala Province). For instance, Mozambique has only one boat available to monitor the vast maritime environment (Vas 2011). As in the case of Sofala, which has around $178 \mathrm{CFCs}$, the provincial Department of Fisheries has only one car and three motorbikes to monitor the artisanal fishing activity. Information regarding the monitoring and control of artisanal fishing activity in Beira gathered from the task force members revealed that the frequency of the monitoring depends on the availability of transport to access the fishing sites. Furthermore, unless accompanied by the police, which seldom happens, monitoring officials could not apprehend erring fisherman nor confiscate and destroy illegal fishing gear.

Control and monitoring of artisanal fishing activity in Praia Nova is not regular. When monitoring does take place, it is usually once in a month or June. Until the end of the field visit and the interviews with the fishermen during the month of June, there wasn't any visit from the provincial Department of Fisheries to oversee the artisanal fishing activity since January 2011. However, the CFC in Praia Nova claims that inspection is done once a month to check if the fishermen are licensed (Lorenzo 2011). Similarly, monitoring of artisanal fishing activity at Biques site is performed irregularly. Sometimes, small size nets such as mosquito nets are confiscated during these site visits.
The provincial Department of Fisheries does not undertake regular inspection/visits to the Djalane site due to the site location. The site is located approximately $30 \mathrm{~km}$ from the provincial department of fisheries' office, which is suggestive of the huge logistic constraints faced by the task force responsible for the control and monitoring of the artisanal fishing activity.

\section{Effectiveness of Fishing Regulations}

Through the Fishing Act, the National Marine Regulation, the Conservation Act, the Environmental Act and also the Constitution, the Department of Fisheries is equipped with the regulatory tools necessary to establish liability and take action against misuse of the marine environment and its species. Currently, the artisanal fishermen who do not comply with the above described regulations which include the recommended mesh size of the fishing nets and licensing requirements are punished with fines. In the worst case scenario the fish landed is confiscated and the fishing gear are destroyed.

The Department of Fisheries along with stakeholders such as the IDSSF and non-governmental agencies has been promoting informative campaigns on the negative impacts of mosquito net traps and other small mesh nets. These campaigns were also used to provide information on the policies and regulations governing the fishery sector (Miguel 2011). Nevertheless, the level of implementation or enforcement of the regulations and policies is still inadequate. Thus, whereas the regulations and policies for the management of the fishery sector are well formulated, their enforcement is still far from being effective. This is mainly due to the various constraints, including financial and human resource/capacity and logistic problems, faced by the Department of Fisheries in the performance of its routine duties (Miguel 2011).

\section{Artisanal Fishermen's Awareness of the Regulations}

Governments worldwide have designed environmental and conservation policies and regulations as tools for enhancing effective management of the resources and the environment we live in (Lee and Midana 2013). Indeed, the impact of poorly controlled artisanal fishing is a matter of concern to several countries (Thorn- 
ton and Beckwith 1997; Blythe et al. 2014). Mozambique has also promulgated various policies and regulations to address the management of the fishing sector for the benefit of all Mozambicans. The policies and regulations include the Fishing Act 3 of 1990 and the General Regulation for Marine Fishing Act 43 of 2003. With a view to achieving responsible fishing and conservation of the marine environment and resources, the Department of Fisheries takes the issue of spreading information on the policies and regulations to those involved in the fishing activity very seriously. However, officials from the Department of Fisheries, NIFR, IDSSR and CFCs, estimate the number of artisanal fishermen in Beira who might be aware of the policies and regulations governing this form of fishing activity as below 50 per cent (IDSSF, 2006). However, the interview with the artisanal fishermen revealed that most of them are actually aware of the policies and regulations governing the fishing sector. The field work further demonstrates that the artisanal fishermen are also aware of the need to pay a licensing fee or tax in order to legally take part in artisanal fishing activity. They also know the mesh size of nets required by legislation but do not comply because they claim that compliance would drastically reduce the catch volume.

As discussed earlier on, the Department of Fisheries has introduced CFCs that have been co-managing the artisanal fishing sector. Both have been engaged in awareness campaigns on the fishing regulations through community sensitization. Nevertheless, the researcher believes that more can be done to convince the practitioners of artisanal fishing that non-compliance has serious economic consequences for their livelihood.

\section{Environmental Impact of Artisanal Fishing in Beira}

The impact of artisanal fishing gear is still a challenge in several developing countries (Blaber et al. 2000; Blythe et al. 2014). Its impacts on the marine ecosystem vary from direct to indirect including the alteration of the ecosystem's health and a reduction in the species diversity (Jennings and Kaiser 1998). Mangi and Roberts (2006) point out that artisanal fishing involving beach seining represents a danger since it may cause the most direct physical damage to ma- rine ecosystems, particularly on coral reefs. Mozambican officials from the Department of Fisheries concur, asserting that the capture of larvae and juveniles is the most severe negative environmental impact. "The prevalence of larvae and juveniles in the landings can be closely correlated with the use of small meshes and mosquito nets" (Vas 2011). This in spite of the fact that Chapter 3, section 1, article 29 (1) of Decree no 3/2002 of 10 December 2002, of the marine regulation, forbids the capture of larvae and juveniles, unless authorized in terms of conditions specified by the Department of Fisheries and the Fishing Management Committee (Bulletin 2002).

Thus, the use of mosquito nets is discouraged not only because the regulations forbid it but also because of its potential to reduce the target stock. Both officials from the Department of Fishing and stakeholders (IDSSF, NIFR and CFCs) as well as fishermen have come to realize that the productivity (in terms of quantity and fish size) of some fishing gear such as beach seining has been declining in recent years. Reasons for the reduction include the excessive fishing by fishermen over the years. For instance, fishermen in Njalane, Palmeiras and Biques have come to notice such a change in catch effort but most of them ignore the underlying cause. Again, Palmeiras and Biques are the sites where the excessive use of chicocota may not only be responsible for reducing the species but causing damage to the sea bed. This is particularly the case because the chicocota is a fixed trap which is on the site 24 hours each day of the week. A detailed study of the issue is recommended in order to gather data that will enable the assessment of the extent to which this damage is occurring and the impacts thereof.

\section{Degree of Compliance with Fishing Regulations}

After a careful analysis of Mozambique's policies and regulations for the management of the fisheries and the fishing sector, the researcher is of the view that legislation for management of this sector and its environment is very well formulated and of direct relevance. The Department of Fisheries admitted, though, that the issue of legal compliance of the artisanal fishing sector in Mozambique, particularly in Beira, was not always at the top of the government's agenda. However, with the increasing pressure on 
marine ecosystems and fisheries resources, sustainable management of the fishery sector is now recognized and incorporated in policies, legislation and development agenda.

The history of artisanal fishing in Njlane shows that the chicocota was once used by the artisanal fishermen and that the people of Njalane used to cut mangrove forest for use as wood. The mangrove ecosystem destruction along with the excessive fishing resulted in overexploitation not only of the target stock but also of several other species. However, a rescue plan designed by IDSSF has restored the mangrove forest in Njalane and increased awareness of the negative impacts of both mangrove destruction and chicocota use. Currently, the level of compliance of artisanal fishermen in Njalane is by far better than in Palmeiras, Biques and Praia Nova.

\section{CONCLUSION}

Mozambique has identified ecosystem management as a primary goal to sustain the integrity of its marine ecosystems. However, the challenges to overcome and achieve the desired goal are enormous. To begin with, the low level of education and awareness of regulations guiding the fishing sector make implementation difficult. Furthermore, a key issue contributing to the dependency on and risks of certain artisanal fishing gear is the dire socio-economic conditions under which the artisanal fishermen in Beira live - which compels them to use inappropriate fishing nets such as chicocota. The system in place to control and monitor artisanal fishing in the study area is also very weak. For instance the department of fishing in Beira, Sofala Province, has six people tasked with controlling and monitoring 178 fishing centres spread across the coastal region.

The fact that artisanal fishermen learnt the art of fishing from their ancestors can be seen as a burden because the change of mind set required to move from old fishing methods to more improved and environmentally friendly ones is proving difficult. Apart from that, the artisanal fishermen believe that using nets with small mesh sizes maximizes output. Various issues of major concern have been identified from the interviews with the task force group responsible for the control and monitoring of fishing activity and the marine ecosystem in Beira. These include logistic difficulties arising from transport constraints - the group (at the time of the research) relied on just one car and three motorbikes to monitor the vast coastal environment. Furthermore, the officials only get to go to the fishing centres located in far places once a year because access to these centres is via boat or long car trips on extremely poor roads.

\section{RECOMMENDATIONS}

Though the effectiveness of the CFC is yet to be proven it can be seen as a step forward in better management of the artisanal fishing sector. Sound management of marine resources and the environment in Beira is urgent and needs to be addressed more proactively by the Department of Fisheries and related institutions, because overexploitation of fisheries can take years to be detected and this may be exacerbated by the lack of control and monitoring of fishing activity and the marine environment.

A detailed study on the impact of the use of the chicocota and beach seining on the Sofala Bay ecosystem should be undertaken in order to have scenarios of the pattern and behaviour of affected species. In doing so, it will be possible to gather data on the quantity of juvenile species caught by these nets, with the aim of designing a better strategic plan for the management of marine resources while guaranteeing right to the fishing environment within the framework of sustainable development. Further education of artisanal fishermen in Beira regarding the adverse impacts of fishing gear as well as legislation and policies guiding fishing activities would improve the artisanal fishing sector. Thus, it is recommended that both the Department of Fisheries and stakeholders make use of mass media education with locally available mass communication resources such as targeted radio programmes to sensitize the population in general and the fishing community in particular about the need to comply with laws and regulations governing the fishing sector to the benefit of all. The findings of this study also revealed that more than $75 \%$ of artisanal fishermen in Beira are unaware of the existence of the fishery development fund. Thus, there is a need to increase awareness among the artisanal fishing community of a government institution that was specif- 
ically designed to boost the fishing sector in Mozambique. Finally, for it to be effective, marine and fishing policies and regulations should be used not in isolation but in complement with other non-fisheries legislation, such as the Constitution of the country which indirectly impact on the fishing sector.

\section{REFERENCES}

Blaber SJM, Cyrus DP, Albaret JJ, Ching CV, Day JW, Elliott M, Fonseca MS, Hoss DE, Orensanz J, Potter IC, Silvert W 2000. Effects of fishing on the structure and functioning of Estuarine and nearshore ecosystem. Journal of Marine Science, 57: 590-602.

Blythe JL, Murray G, Flaherty, M 2014. Strengthening threatened communities through adaptation: Insignts from coastal Mozambique. Ecology and Society, 19(2): 6-15.

Brill GC, Raemaekers SJPN 2013. A decade of illegal fishing in Table Mountain National Park (20002009): Trends in the illicit harvest of abalone Haliotis midae and West Coast rock lobster Jasus lalandii. African Journal of Marine Science, 35(4): 491-500.

Bulletin from the Republic 2002. Decree No 3/2002 of 10 December 2002. Official publication of the Republic of Mozambique.

Cochrane KL, Garcia SM 2009. A Fishery Manager's Guidebook. Rome: FAO and Wiley-Blackwell.

Constitution of the Republic of Mozambique 1990. Maputo: Department of Documentation and Information. From <http://confinder.richmond.edu/ admin/docs/Constitution_(in_force_21_01_05) (English)-Mozlegal.pdf> (Retrieved on 20 September 2011).

FAO 2009. FAO/UNEP Expert Meeting on Impacts of Destructive Fishing Practices, Unsustainable Fishing, and Illegal, Unreported and Unregulated (IUU) Fishing on Marine Biodiversity and Habitats. From <http://www.fao.org/docrep/012/i1490e/ i1490e00.pdf 2010-09-05.> (Retrieved on 18 September 2011).

FAO 2007. Fishery Country Profile: The Republic of Mozambique. From <http://www.worldfish.org/GCI/ gci_assets_moz/Mozambique Fishery OverviewFAO.pdf> (Retrieved on 14 September 2011).

Glazewski J 2005. Environmental Law in South Africa. Durban: Lexis Nexis Butterworth.

Goldie J, Douglas B, Furnass B 2005. In Search of Sustainability. Melbourne: CSIRO.

Google Earth 2012. Beira: Mozambique. Digital Globe Data from SIO, NOAA, US NAVY, NGA and GEBCO. From <http://www.nationsonline.org/oneworld/ map/google_map_Maputo.htm> (Retrieved on 24 July 2012)

Ghosh S 2012. Fishery, reproductive biology and diet characteristics of Bombay duck Harpadon nehereus from the Saurashtra coast. Indian Journal of Marine Science, 43(3): 418-426.
Government Gazette No. 5 Republic of Mozambique 2003. Marine Fishing Act No. 5/03. Maputo: Department of Documentation and Information.

Government Gazette No. 39 Republic of Mozambique 1990. Fishing Law No. 3/90. Maputo: Department of Documentation and Information.

Hara WM, Deru J, Pitamber S 2001. Artisanal Fisheries Development Project: Republic of Mozambique. Appraisal Report. Abidjan: African Development Fund.

Hoguane AM 1998. Information on the Eastern African Sea Level. UNESCO: International Oceanographic Commission. Mozambique.

Institute for the Development of Small-Scale Fisheries (IDSSF) 2003. Annotated Bibliography: Artisanal Fisheries Studies in Mozambique 1994 - 2003. IDSSF, Regional Fisheries Information System Project, Department of International Development and Southern Africa Development Community. Mozambique: Department of Documentation and Information. [Institute de Desenvolvimento de Pesca de Pequena Escala (IDPPE)].

Institute for the Development of Small-Scale Fisheries (IDSSF) 2006. Artisanal Fishing Sector Strategic Plan. Maputo: Department of Documentation and Information.

Institute for the Development of Small-Scale Fisheries (IDSSF) 2009. Artisanal Fishing Sector Strategic Plan. Maputo: Department of Documentation and Information.

Jennings S, Kaiser MJ 1998. The effects of fishing on marine ecosystems. Advances in Marine Biology, 34: 201-351.

Lee S-G, Midani AR 2013. National comprehensive approaches for rebuilding fisheries in South Korea. World Journal of Fish and Marine Sciences, 5(6): 709-717.

Lorenzo GK 2011. Community Fishing Centre in Praia Nova (Interviewed on 12 May 2011).

Mangi SC, Roberts CM 2006. Quantifying the environmental impacts of artisanal fishing gear on Kenya's coral reef ecosystems. Marine Pollution Bulletin, 52: 1646-1660.

Miguel EA 2011. Institute for the Development of Small-Scale Fisheries. (Interviewed on 11 May 2011).

Ministry of Fishing and IDSSF 2009. The 2007 Artisanal Fishing Census. Mozambique: National Institute of Statistics.

National Environmental Management Programme (NEMP) 1995. Department of Documentation and Information. From <http://www.mcatoolkit.org/ Country_Analyses/Mozambique.html> (Retrieved on 27 September 2011)

National Institute for Fishery Research (NIFR) 2010. Annual Report. Maputo.

National Institute for Fishery Research (NIFR) 2008. Technical Report on Chicocota Fishing. Activity and the Possible Impact on Marine Environment. Information Bulletin, 43: 25.

National Institute for Fishery Research (NIFR) 2003. The Artisanal Fishery for Shrimps in Nampula and Zambezia Provinces of Mozambique for 1997- 
2002. Maputo: Department of Documentation and Information.

Paul B, Faruque H, Ahsan DA 2014. Consequences of climate change on fish biodiversity in the river Turag, Bangladesh: Community perception study. World Journal of Fish and Marine Sciences, 6(2): 136-141.
The Eastern Africa Marine Ecoregion (EAME) 2007. Sofala Bay. From <http://eame.wiomsa.org/sofala. html.> (Retrieved on 20 August 20 2010)

Thorton J, Beckwith S 1997. Environmental Law. London: Sweet and Maxwell Limited.

Vas JY 2011. Ministry of Fishing. (Interviewed on 12 May 2011). 